\title{
THE
}

\section{Turbulent supply of nutrients to phytoplankton at the New England shelf break front}

\author{
Burke Hales \\ Dave Hebert \\ University of Rhode Island \\ John Marra
}

Follow this and additional works at: https://digitalcommons.uri.edu/gsofacpubs

Terms of Use

All rights reserved under copyright.

\section{Citation/Publisher Attribution}

Hales, B., D. Hebert, and J. Marra (2009), Turbulent supply of nutrients to phytoplankton at the New England shelf break front, J. Geophys. Res., 114, C05010, doi: 10.1029/2008JC005011.

Available at: https://doi.org/10.1029/2008JC005011

This Article is brought to you for free and open access by the Graduate School of Oceanography at DigitalCommons@URI. It has been accepted for inclusion in Graduate School of Oceanography Faculty Publications by an authorized administrator of DigitalCommons@URI. For more information, please contact digitalcommons-group@uri.edu. 


\title{
Turbulent supply of nutrients to phytoplankton at the New England shelf break front
}

\author{
Burke Hales, ${ }^{1}$ Dave Hebert, ${ }^{2}$ and John Marra $^{3}$ \\ Received 10 July 2008; revised 7 November 2008; accepted 16 January 2009; published 13 May 2009.
}

[1] We present observations from deployments of a microstructure turbulence instrument (the Towed Microstructure and Auxiliary Sensor Instrument) aboard a pumping profiling vehicle (the Lamont Pumping SeaSoar) towed behind a research vessel at the New England shelf break front in August 2002. From these we determined coincident fine-scale vertical eddy diffusivity and gradients of nitrate, phosphate, and silicate on several transects spanning the front. We then quantified vertical turbulent nutrient fluxes through the base of the euphotic zone (defined as the 1\% light level), the base of the density transition zone, maximum nutrient gradients (the nutriclines), and the depth of maximum stratification (the pycnocline). Vertical eddy diffusivity estimates spanned a wide range from near-molecular levels at the pycnocline to values exceeding $10^{-3} \mathrm{~m}^{2} \mathrm{~s}^{-1}$ at depth and in the surface layers. Vertical nutrient fluxes were maximal at the $1 \%$ light level and decreased by 2 orders of magnitude as they moved upward through the water column to the depth of the pycnocline. Nutrient fluxes were enhanced shoreward of the front because of high mixing rates and nutrient gradients at the depth of the $1 \%$ light level. Nitrate fluxes there averaged about $6 \times 10^{-5} \mathrm{mmol} \mathrm{N} \mathrm{m}^{-2} \mathrm{~s}^{-1}$, sufficient to support a net community productivity of $30 \mathrm{mmol} \mathrm{C} \mathrm{m} \mathrm{m}^{-2} \mathrm{~d}^{-1}$. Seaward of the front, these fluxes averaged about $1 \times 10^{-5} \mathrm{mmol} \mathrm{N} \mathrm{m}^{-2} \mathrm{~s}^{-1}$ and would support correspondingly lower productivity. A small part of the upward flux appeared to support a silicifying community of phytoplankton that consumed phosphate in proportion to nitrate at about double the canonical Redfield stoichiometry.

Citation: Hales, B., D. Hebert, and J. Marra (2009), Turbulent supply of nutrients to phytoplankton at the New England shelf break front, J. Geophys. Res., 114, C05010, doi:10.1029/2008JC005011.

\section{Introduction and Background}

[2] The New England shelf break front separates cold, fresh, low-clarity shelf water from warm, salty, clear slope water. It has long been recognized as a region of elevated biomass [Malone et al., 1983; Houghton and Marra, 1983; Marra et al., 1990]. This elevated biomass has been linked to physical concentration mechanisms [e.g., Ryan et al., 1999a] and to enhanced growth rates [Marra et al., 1990]. This front has long been considered a region of high biological productivity on the basis of remote sensing and in-water observations [Malone et al., 1983; Houghton and Marra, 1983; Ryan et al., 1999b], but the mechanisms supporting this are unclear. The notion that convergence at the front serves to physically concentrate biomass, without any increase in cell-specific growth rates, has been supported by some observations of meanders in the shelf

\footnotetext{
${ }^{1}$ College of Oceanic and Atmospheric Sciences, Oregon State University, Corvallis, Oregon, USA.

${ }^{2}$ Graduate School of Oceanography, University of Rhode Island, Narragansett, Rhode Island, USA.

${ }^{3}$ Aquatic Research and Environmental Assessment Center, Brooklyn College, Brooklyn, New York, USA.
}

Copyright 2009 by the American Geophysical Union. 0148-0227/09/2008JC005011 break jet [Ryan et al., 1999a]. Contrastingly, Marra et al. [1990] hypothesized that the combination of shelf waters high in nutrients but low in optical clarity and stratification with slope waters depleted in nutrients but well stratified and clear led to optimal illumination, stability, and nutrient conditions for enhanced specific growth rates. The modelbased results of Gawarkiewicz and Chapman [1992] and Chapman and Lentz [1994], bolstered by the deliberate tracer release and high-resolution survey work of Houghton and Visbeck [1998], offered a new possibility, namely, that upwelling at the base of the front might supply nutrients to plankton in illuminated waters at the front through advection.

[3] To examine the possibility of an advective supply of nutrients, we performed high-resolution surveys of the biogeochemistry and physics of the New England shelf break front during summer 2002. Composite cross-frontal sections for June and August, representing the mean state of the hydrography of the front during those two time periods, are presented by Hales et al. [2009]. The first-order interpretation of that work was that the biomass and, presumably, the productivity were largely controlled by one-dimensional vertical processes. Biomass maxima were well correlated with features such as stratification and limiting-nitrate horizons. In August, we added microstructure measurements of turbulence to the measurement suite and combined 


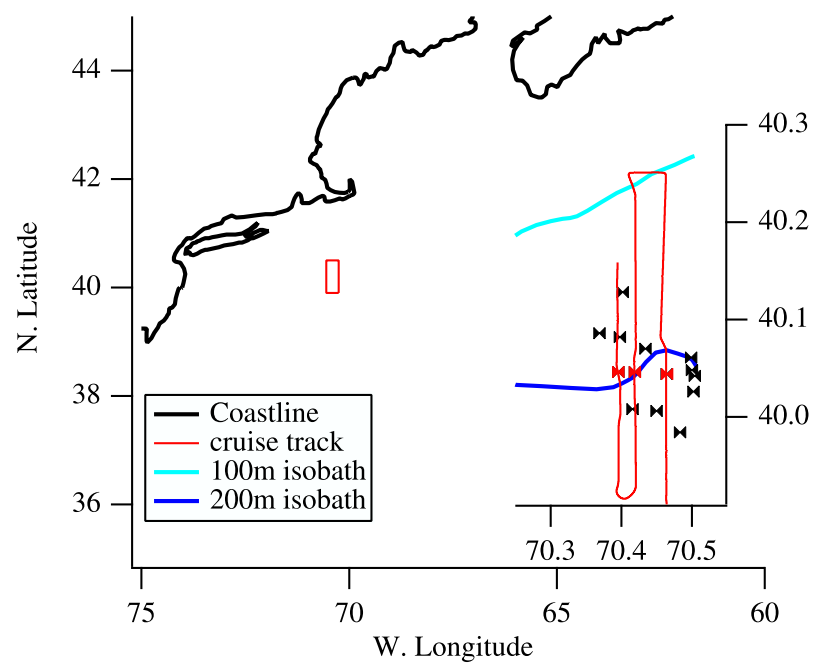

Figure 1. Study area (red box) in the Mid-Atlantic Bight, expanded in the inset. Ship's track (red line) shows the crossfrontal surveys carried out on YD222 in 2002. Symbols represent front locations for these surveys (red symbols) and others on the same cruise (black symbols), determined as described by Hales et al. [2009]. Light and dark blue contours show the positions of the $100 \mathrm{~m}$ and $200 \mathrm{~m}$ contours, respectively.

these with the nutrient measurements of Hales et al. [2009] to quantify the vertical turbulent flux of nutrients to productive layers. These flux estimates are described and discussed below.

\section{Experimental Setting and Methods}

\subsection{Experimental Setting}

[4] The field experiments in June and August 2002 are discussed in detail by Hales et al. [2009]. Here we focus on three transects of the front that were executed on 11 August (Figure 1), during which we crossed the front three times between the hours of 0800 and 2000 LT.

\subsection{Lamont Pumping SeaSoar}

[5] Data were collected using the Lamont Pumping SeaSoar (LPS) towed undulating vehicle [Hales and Takahashi, 2002], modified as described by Hales et al. [2009]. This towed vehicle undulated between depths of approximately 5 and $75 \mathrm{~m}$ at a nominal dive/climb rate of $0.4 \mathrm{~m} \mathrm{~s}^{-1}$. At the nominal $6 \mathrm{knot}\left(3 \mathrm{~m} \mathrm{~s}^{-1}\right)$ towing speed of the ship, roughly two vertical profiles were completed within each kilometer along track. Given the sawtooth shape of the vehicle track, however, and the resulting depthvariable sample spacing, it is probably best to assume that the along-track resolution of the LPS is nominally $1 \mathrm{~km}$. The LPS carried an array of sensors for in situ measurements of physical and bio-optical parameters. Of particular relevance to this paper were the Sea-Bird 9+ conductivitytemperature-depth-based measurements of temperature, salinity, and depth, the WETLabs WETStar chlorophyll fluorometer, and the Biospherical QSP200L logarithmic photosynthetically active radiation (PAR) sensor. In addition, the LPS carried a pump that delivered seawater samples to the shipboard laboratory. Analytical measurements of nutrients (nitrate, phosphate, and silicate presented here) were made in a split of the seawater stream delivered to the ship through the tow cable by the pump aboard the LPS. Nutrients were analyzed following the high-speed flow injection analyses described by Hales et al. [2004], modified for continuous segmented flow as described by Hales et al. [2005]. Measurement times were corrected for analytical lags of the individual systems and the sampling lag between LPS vehicle and shipboard laboratory and placed in the context of the in situ measurements (following Hales and Takahashi [2002, 2004] and Hales et al. [2004, 2005]). Lag times here and in earlier publications were estimated to have uncertainties of less than $\pm 2 \mathrm{~s}$, corresponding to less than $\pm 1 \mathrm{~m}$ uncertainty in vertical position. Measurement frequencies for nitrate, silicate, and phosphate were approximately $0.9,0.8$, and $0.6 \mathrm{~Hz}$, respectively. Analytical response times for these measurements were $\sim 7 \mathrm{~s}$, similar to the estimated smoothing associated with sample delivery through the towing cable [Hales and Takahashi, 2002].

\subsection{Microstructure Measurements}

[6] On this and selected other surveys, we mounted the Towed Microstructure and Auxiliary Sensor Instrument (TOMASI) aboard the LPS. TOMASI is a version of the Vertical Microstructure Profiler [Rainville and Winsor, 2008], built by Rockland Scientific International (RSI), that measures turbulence-scale temperature with a FP07 fast response thermistor, conductivity with a Sea-Bird microconductivity probe (SBE-7), and velocity shear with probes supplied by RSI (SPM38). The data are transmitted in real time to a data acquisition computer on the ship. During this first set of deployments, there were no velocity shear sensors, and the microconductivity circuit and sensor were not working properly. Thus, the data from the fast thermistor were used to estimate the turbulent mixing rate. The temperature microstructure was recorded as the signal plus its derivative [Mudge and Lueck, 1994] at $512 \mathrm{~Hz}$. The variance of the temperature (spatial) gradient was obtained by integrating the temperature derivative spectrum for each $1 \mathrm{~s}$ block and using the LPS speed through the water to convert the temporal gradient to a spatial gradient. We used this temperature gradient variance to estimate the thermal variance dissipation rate, $\chi_{T}=6 D(d T / d x)^{2}$, where $D$ is the thermal molecular diffusivity, $1.49 \times 10^{-7} \mathrm{~m}^{2} \mathrm{~s}^{-1}$.

[7] Although Gregg [1999] has questioned the use of this thermistor at high fall rates $\left(\sim 1 \mathrm{~m} \mathrm{~s}^{-1}\right)$, Rainville and Winsor [2008] have shown good agreement with $\chi_{T}$ estimates based on coincident microconductivity measurements at these high fall rates. As a check of how much temperature gradient variance was not resolved, the method of Washburn et al. [1996] was used. An estimate of the turbulent kinetic energy dissipation rate, $\varepsilon$, was made by assuming that the overturning scale $L_{\mathrm{O}}$, the average temperature fluctuation for a $1 \mathrm{~s}$ block divided by the mean vertical temperature gradient, is equivalent to the buoyancy or Ozmidov scale $\left(\varepsilon / N^{3}\right)^{1 / 2}$, where $N$ is the local buoyancy frequency. Itsweire [1984] has shown that the overturning scale is of the same order as the Thorpe scale [Thorpe, 1977], and many studies [e.g., Dillon, 1982; Moum, 1996; Klymak et al., 2008] have shown that the Thorpe scale is approximately the same as the Ozmidov scale. With the intermittent nature of turbulence, the estimate of $\varepsilon$ based on this method is only an order of magnitude 
estimate [Washburn et al., 1996]. With this dissipation rate estimate, the fraction of the Batchelor spectrum [Batchelor, 1959] resolved by the thermistor could be determined. This allowed us to estimate a "correction factor" that ranged from 1 to about 7 (95\% confidence interval) for the data presented below, well within the order of magnitude level uncertainties in estimation of $\varepsilon$ by this approach. Technically, we could have increased our $\chi_{T}$ estimates (and resulting diffusivities) by this factor, but we decided to keep our estimates conservative and simply state that our mixing rates may represent a lower estimate of the true turbulent mixing. The correction factor showed no coherent spatial structure or any correlative relationship to any of the other properties or depth horizons discussed here. The spatial structure of diffusivities using this correction factor is thus similar to that of the diffusivities used here, and the interpretation of the relative patterns is unaffected.

\subsection{Gridded Sections}

[8] Individual cross-frontal sections were transformed into uniformly spaced gridded representations following the approach of Hales et al. [2006, 2009] and Hales and Takahashi [2004]. Briefly, actual data were transferred into grids with horizontal and vertical resolutions of 222 and $0.5 \mathrm{~m}$, respectively. Grid cells were filled on the basis of an inverse distance squared averaged weighting scheme, where horizontal distances were scaled relative to vertical distances by a factor of 0.001 (points $0.5 \mathrm{~m}$ distant in the vertical were weighted equivalently to points weighted $500 \mathrm{~m}$ distant in the horizontal). Data within $5 \mathrm{~km}$ horizontally and $5 \mathrm{~m}$ vertically of each grid cell were included in the weighted average, and points at the outer limits of these distances were weighted 100 times less than data located within the grid cell. Gridded sections are presented as distributions of each property in depth and cross-frontal distance, where the location of the front is chosen as the seawardmost occurrence of the $9^{\circ} \mathrm{C}$ isotherm, following Hales et al. [2009]. This definition of the front, while operational, was simple and robust and coincided with the position of the frontal jet, as realized by acoustic Doppler current profiler (ADCP) velocity profiles, and the position of greatest cross-shelf property gradients. During this cruise the front was centered approximately on the $200 \mathrm{~m}$ isobath (Figure 1).

[9] Since turbulence is highly intermittent, any estimation of mixing rates requires using average values of microstructure dissipation rates. In order to maintain the spatial resolution and structure of the frontal region, we produced and present the composite of the three front crossings, after the individual sections were shifted to account for the small variability in the position of the front. This results in some cross-track averaging of the properties presented but an increase in the along-track data density, as multiple surveys are collapsed into one composite.

\subsection{Derived Parameters}

[10] Some parameters were calculated from the gridded sections. Distributions of vertical nutrient and temperature gradients and the square of the Brunt-Väisälä frequency $\left(N^{2}\right)$ were determined by a two-pass process in which gradients were first calculated using a centered, third-order polynomial fit to the gridded data from $2 \mathrm{~m}$ below to $2 \mathrm{~m}$ above each grid cell. Gradients that fell below analytical resolution over that depth range were recalculated using a vertical span of $4 \mathrm{~m}$ below to $4 \mathrm{~m}$ above the chosen grid cell.

[11] Euphotic and pycnocline depths were determined as described by Hales et al. [2009]. Briefly, euphotic depths were determined as the depth by which $4.6 e$-folding scales ( $1 \%$ light level) had been reached, by integrating the $K_{\mathrm{PAR}}$ data calculated from in situ PAR measurements made with the sensor mounted atop the LPS. A spectral model of seawater light attenuation (Morel and Maritorena [2001] as represented by Strutton and Chavez [2004]) was used to calculate attenuation in near-surface waters that the LPS did not sample. The $1 \%$ light level here corresponds to a daily integrated irradiance of about $0.5 \mathrm{~mol}$ quanta $\mathrm{m}^{-2}$, using either the clear-sky surface irradiance predicted for this location and time [e.g., Letelier et al., 2004; Vaillancourt et al., 2005] or the quantitatively consistent surface irradiance measured with shipboard PAR sensors on this cruise (maximum noontime irradiances of about $2500 \mu \mathrm{mol}$ quanta $\mathrm{m}^{-2} \mathrm{~s}^{-1}$; data not shown). The irradiance at the $1 \%$ light depth calculated here is at the lower end of that sufficient to support net photosynthetic nutrient uptake [e.g., Marra, 2004], and this depth horizon is a reasonable lower boundary of the photosynthetic layer. Pycnocline depths were determined from the vertical maxima in $N^{2}$ distributions calculated as described above. The threshold of $N^{2}=2.8 \times 10^{-4} \mathrm{~s}^{-2}$ $\left(N=60\right.$ cycles $\left.\mathrm{h}^{-1}\right)$ was operationally chosen as the value defining the shallowest and deepest positions of the density transition zone [Johnston and Rudnick, 2009]. Nutricline depths were chosen as the depths of the maximum vertical nutrient gradients.

[12] The diapycnal turbulent mixing rate, $k_{T}$, was determined using the Osborn and Cox [1972] assumption that the temperature variation dissipation rate is balanced by the variance production rate by the turbulent flow acting on the mean temperature gradient, or, explicitly,

$$
k_{T}=\frac{\chi_{T}}{2\left(\frac{\partial T}{\partial z}\right)^{2}} .
$$

Because this estimation of turbulent mixing is unreliable for very small vertical temperature gradients, we limited calculation to situations where absolute vertical temperature gradients were $>0.01^{\circ} \mathrm{C} \mathrm{m}^{-1}$. This corresponds to about 5-10 times the calculation uncertainty in the vertical temperature gradient, given the resolution of the temperature sensors and the smoothing associated with the gridding and differentiation procedures. This limit minimizes erroneously high calculations of $k_{T}$ in regions with vertical temperature gradients that approach our uncertainty limits.

[13] We also calculated turbulent mixing rates from the estimates of $\varepsilon$ (described previously) and $N^{2}$ (following Osborn [1980]), and these yielded consistent patterns and magnitudes of mixing rates. As a final check, we calculated gradient Richardson number distributions derived from our $N^{2}$ values and vertical shear calculated from shipboard ADCP data, and estimated mixing rates using the LOAM (N. Naik, The Lamont Ocean Atmosphere Mixed-layer model, LOAM documentation, http://rainbow.ldeo.columbia.edu/ climategroup/loam) modification of the Pacanowski and Philander [1981] approximation, as described by Robertson [2006]. These results are again consistent with the $k_{T}$ values 


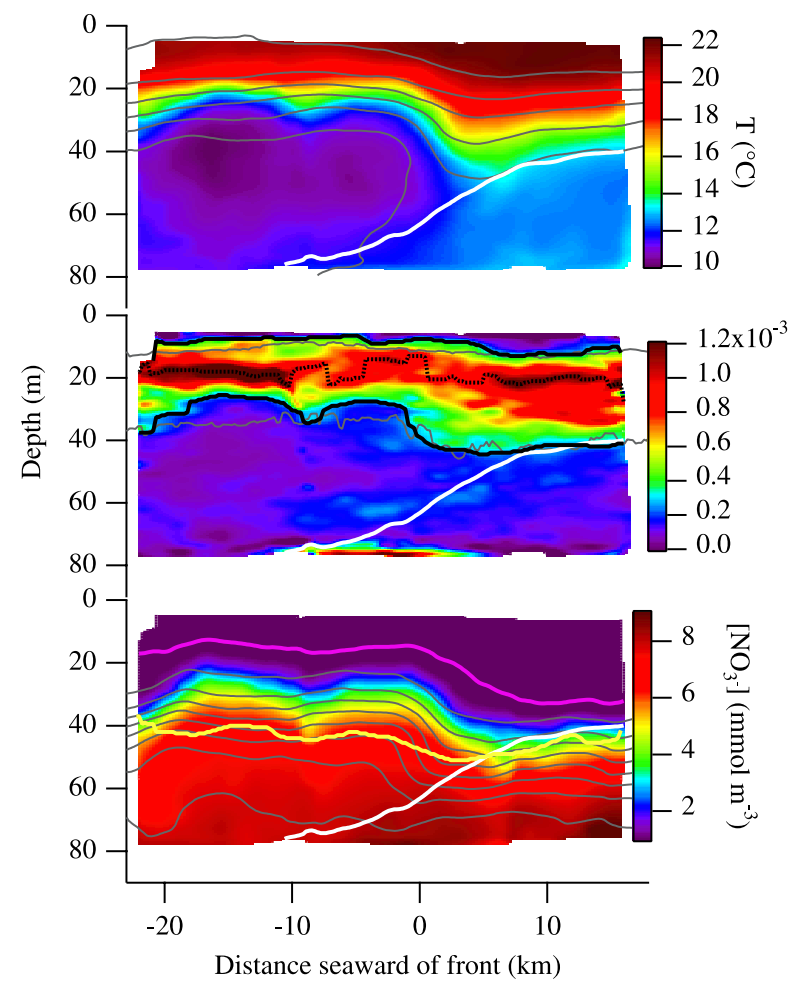

Figure 2. Composite distributions of (top) temperature, (middle) $N^{2}$ (the buoyancy frequency squared), and (bottom) $\mathrm{NO}_{3}{ }^{-}$for the three front crossings on YD223, 2002. The color maps show the property distributions for YD223; the light gray contours are taken from the composites of these same properties for the whole cruise, as presented by Hales et al. [2009]. The heavy white line shows the position of the 26- $\sigma_{\mathrm{t}}$ density surface, whose seaward shoaling characterizes the frontal zone. In Figure 2 (middle), the heavy solid black contours show the upper and lower limits of the density transition zone, while the dotted black contour shows the position of the pycnocline, or depth of maximum stratification. Gray contours show the position of the density transition zone for the cruise composite. In Figure 2 (bottom), the magenta contour shows the position of the limiting $\mathrm{NO}_{3}{ }^{-}$ horizon, while the yellow contour shows the position of the $1 \%$ light level.

but do not contain the detailed vertical structure of those obtained with the in situ microstructure measurements and are not presented here.

[14] Nutrient fluxes were calculated from

$$
F_{\text {nut }}=-k_{T} \frac{\partial C_{\text {nut }}}{\partial z}
$$

where $C_{\text {nut }}$ is the concentration of the nutrient in question. Flux calculations were performed only for conditions for which the individual nutrient gradients were far above the resolution of the calculation. We did this to limit the generation of erroneously large fluxes that resulted from the rare coincidence of large values of $k_{T}$ with small, poorly constrained vertical gradient estimates. For nitrate and silicate gradients, this cutoff was $0.04 \mathrm{mmol} \mathrm{m} \mathrm{m}^{-3} \mathrm{~m}^{-1}$; for phosphate, it was $0.002 \mathrm{mmol} \mathrm{m}^{-3} \mathrm{~m}^{-1}$. These thresholds correspond to about 5-10 times the calculation uncertainty in this term, given the resolution of the chemical analyses and the smoothing associated with the gridding and differentiation procedures.

\section{Results}

[15] The basic hydrographic properties observed in these sections are similar to those presented by Hales et al. [2009]. Cross-frontal temperature, density stratification (expressed as buoyancy frequency squared, or $N^{2}$ ), and nitrate $\left(\mathrm{NO}_{3}^{-}\right)$ sections (color maps in Figure 2) are all in good agreement with the distributions of those properties (light gray contours in Figure 2) determined from the composites of all 14 of the cross-shelf sections that were carried out in the cruise. The $N^{2}$ distribution shows a very shallow mixed layer overlying a density transition zone [Johnston and Rudnick, 2009] of intense stratification, in turn overlying a region of decreased stratification at depth. This shows the pattern described by Hales et al. [2009] of shallower density transition zone depths shoreward of the front and greater depths seaward. Distributions of other properties such as salinity, density, phosphate and silicate, and bio-optical estimates of particle densities (not shown) are also in good agreement with the average distributions presented by Hales et al. [2009]. These three sections are thus representative of the mean state of the front for the time period of study.

[16] Mixing in the water column is driven by turbulent energy, expressed here as the temperature variance turbulent dissipation rate, $\chi_{T}$ (Figure 3, top), and limited by thermal stratification (the vertical temperature gradient, Figure 3, middle). These distributions are, as in the case of the hydrographic parameters discussed above, consistent with previous observations of the front. The $\chi_{T}$ distributions show the pattern of elevated values at the surface relative to those at depth and of elevated values that penetrate deeper in the water column at the front as shown previously by Dillon et al. [2003].

[17] The turbulent diapycnal mixing rates $\left(k_{T}\right.$, Figure 3, bottom) are very high in waters at the shallow limits of the density transition zone, as expected because of surface energy inputs and reduced stratification. Within the thermocline, these mixing rates range from about $10^{-6.5} \mathrm{~m}^{2} \mathrm{~s}^{-1}$, about a factor of 2 higher than thermal molecular diffusivity, to $10^{-4.5} \mathrm{~m}^{2} \mathrm{~s}^{-1}$ high relative to pelagic mixing rates [Lewis et al., 1986; Ledwell and Anderson, 2008] but within the range previously observed in coastal settings [Hales et al., 2005; Dillon et al., 2003]. Above and below the density transition zone, rates are significantly greater, exceeding $10^{-3} \mathrm{~m}^{2} \mathrm{~s}^{-1}$.

[18] Composite nutrient gradient distributions are shown for nitrate, phosphate, and silicate in Figure 4. The nitrate gradient field is characterized by a broad maximum with peak values exceeding $0.5 \mathrm{mmol} \mathrm{m} \mathrm{m}^{-3}$. This maximum gradient region, or nitricline, is closely collocated with the base of the density transition zone across the study region. It is significantly shallower than the $1 \%$ light level shoreward of the front and roughly collocated with the 1\% light depth seaward of the front. Phosphate gradient distributions are similar to nitrate distributions; however, the phosphocline is displaced slightly shallower than the nitricline, and the maximum values found at those depths are slightly elevated 


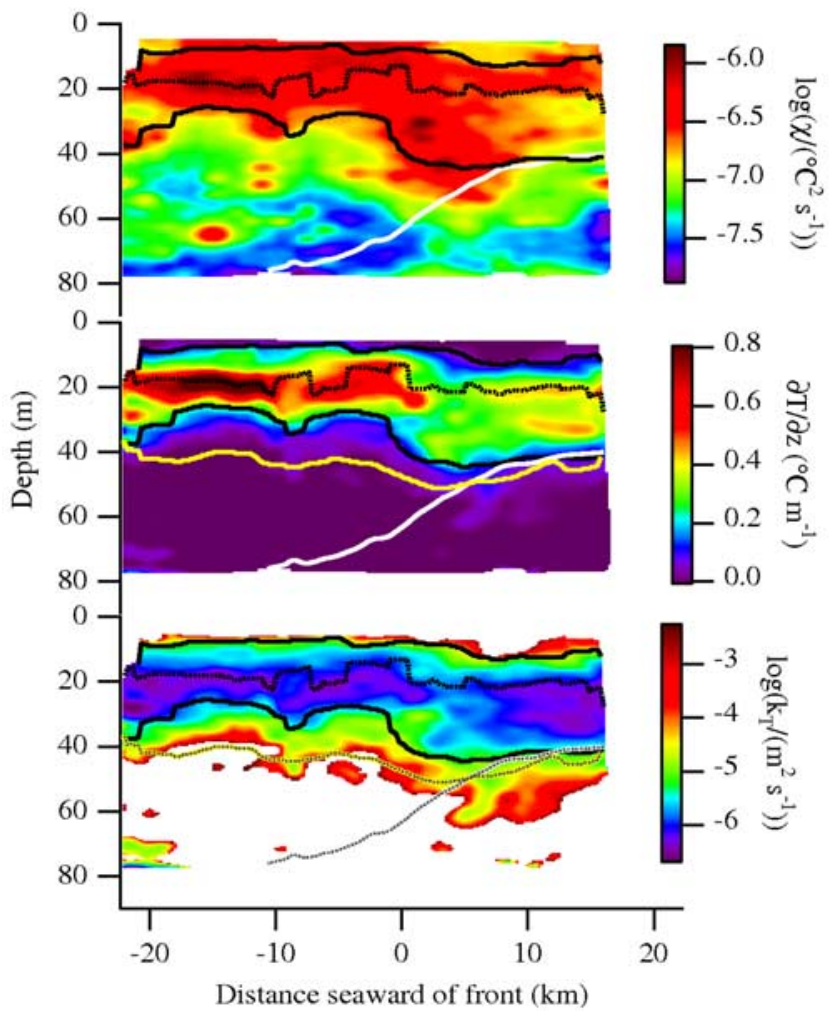

Figure 3. Turbulent mixing across the shelf break front. (top) Temperature variance dissipation rate, $\chi$, as determined from high-frequency temperature sensors aboard TOMASI. (middle) The thermal stratification, as determined from temperature sensors aboard the LPS. (bottom) Vertical mixing rates, $k_{T}$, determined from the ratio of $\chi$ and the temperature gradient squared. The mixing rate $k_{T}$ was not calculated for temperature gradients $<0.005^{\circ} \mathrm{C} \mathrm{m}^{-1}$. Lines representing the density transition zone, 26- $\sigma_{\mathrm{t}}$ surface, and $1 \%$ light level are as in Figure 2. Light dotted lines have been added to the $1 \%$ light level and $26-\sigma_{t}$ contour to highlight their positions against the color scale in Figure 3 (bottom).

over the maximum nitrate gradients when scaled by Redfield stoichiometry. Elevated phosphate gradients exist at depths at and above the pycnocline, even in conditions where the nitrate gradients are negligible. The silicate gradient distributions show a silicline that is also shifted upward in the water column relative to the nitricline and that reaches maximum values only about half of those seen in the nitriclines. Silicate gradients are notably weaker seaward of the front than shoreward.

[19] These composite nutrient flux distributions are illustrated in Figure 5. These are strongly influenced by the highly variable $k_{T}$ distributions, with highest values generally found at depth, but the influence of the nutrient gradients is also apparent as well. Nitrate fluxes approach background levels at the pycnocline and above, while phosphate and silicate pass through a minimum at the pycnocline and show elevated values at shallower depths.

[20] While the gridded composite sections are useful for illustrating the general distributions of the properties of interest, we also present the fluxes through several hydro- graphically important surfaces. First, we chose the $1 \%$ light level as representative of the deepest horizon at which phytoplankton can maintain net consumption of nutrients [e.g., Marra, 2004]. Second, we chose the base of the density transition zone as a depth at which stability may favor enhanced photosynthetic activity in well-illuminated, nutrient-replete waters. Third, we examined the depths of each nutricline to evaluate the fluxes at the depths where gradients were maximal. Finally, we studied fluxes through the pycnocline, representing the shallowest barrier to mixing to the surface.

[21] Fluxes for each nutrient through these horizons are shown in Figure 6. In all cases, fluxes through the pycnocline are lower than at any other horizon. For $\mathrm{NO}_{3}^{-}$, flux through this horizon is lower than through any of the deeper horizons, but for $\mathrm{PO}_{4}^{3-}$ and $\mathrm{Si}$, flux through the pycnocline approaches the fluxes through the nutriclines shoreward of the front. Fluxes through the three deepest horizons (the $1 \%$ light level, the base of the density transition zone, and the nutriclines) are low and similar seaward of the front for each nutrient. The most striking feature of all three nutrients' flux distributions is the strong increase in the flux through the $1 \%$ light level shoreward of the front. This increase approaches an order of magnitude or more over the lower fluxes seaward of the front.

[22] Examination of the fluxes through these horizons shows coherence among the nutrients. There are, however, differences in the flux ratios on the different horizons. The variations in flux ratios are independent of turbulent mixing estimates, as they were all calculated at the same location, and thus $k_{T}$ terms cancel out. This is illustrated in the flux-flux

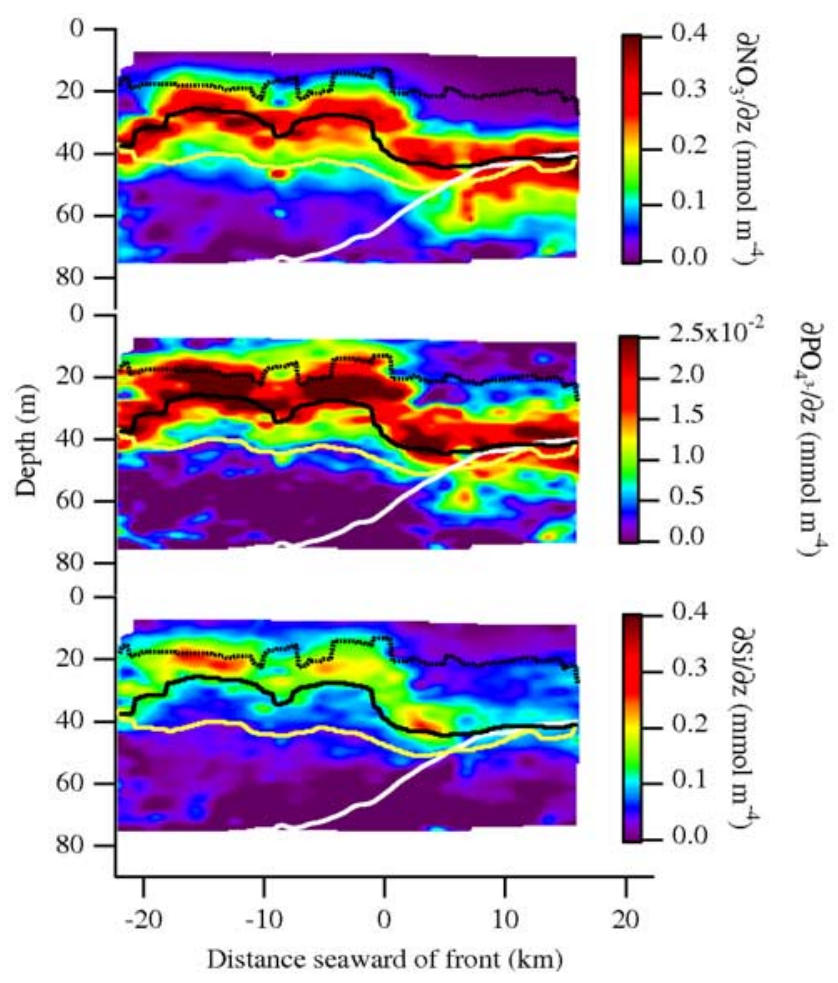

Figure 4. Nutrient gradients across the front. Contours are as in Figure 3. Lines representing the density transition zone, 26- $\sigma_{\mathrm{t}}$ surface, and $1 \%$ light level are as in Figure 2. 


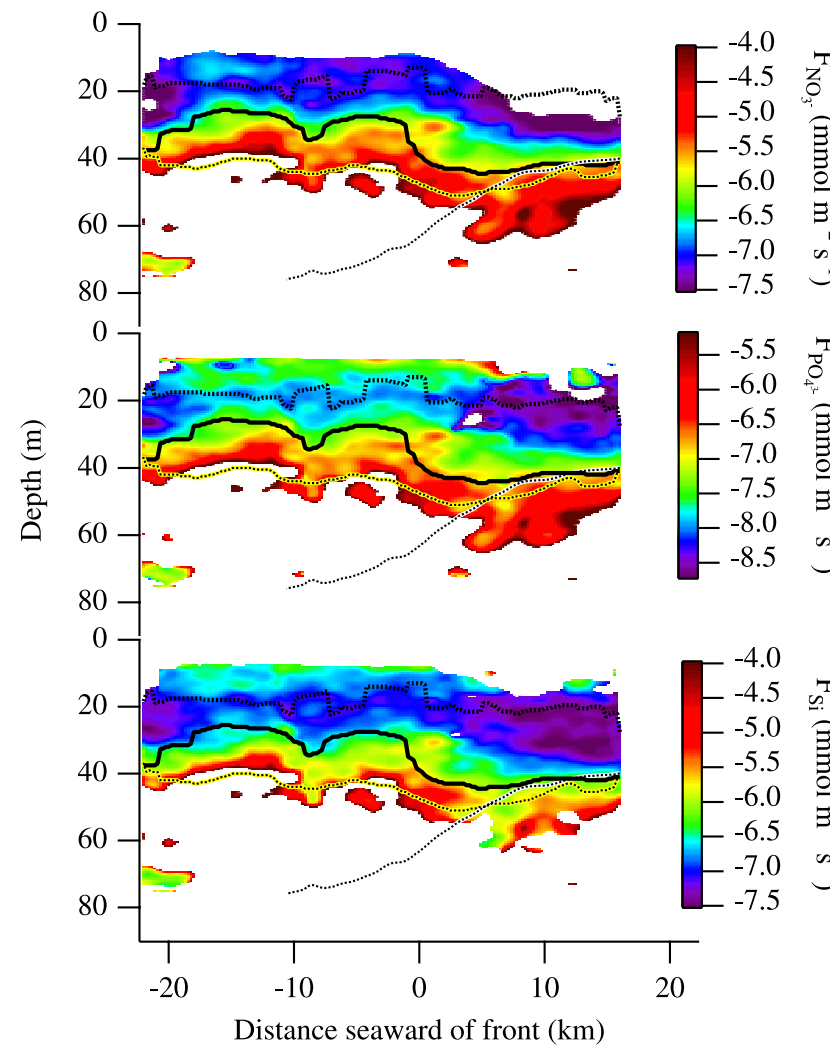

Figure 5. Nutrient fluxes across the front, calculated from the gradients shown in Figure 4 and the vertical turbulent mixing rates shown in Figure 3. To minimize amplification of uncertainty, fluxes were not calculated for $\mathrm{NO}_{3}{ }^{-}$and $\mathrm{Si}$ gradients below $0.02 \mathrm{mmol} \mathrm{m}^{-4}$, or $\mathrm{PO}_{4}{ }^{3-}$ gradients below $0.00125 \mathrm{mmol} \mathrm{m}^{-4}$. Contours are as in Figures 3 and 4 . Light dotted lines have been added to the $1 \%$ light level and $26-s_{t}$ contour to highlight their positions against the color scale.

relationships shown in Figure 7. At the depth of the 1\% light level, where all fluxes are highest, nitrate is being transported upward in approximately Redfield proportion to phosphate but significantly in excess of the 1:1 nitrate to silicate ratio expected for phytoplankton communities dominated by nutrient replete diatoms. At the base of the density transition zone, these generalities persist, although the silicate fluxes have moved closer to the 1:1 line. Upon reaching the pycnocline, silicate and phosphate fluxes exceed Redfield proportionality to the nitrate fluxes. By this depth the nitrate is nearly exhausted, and nitrate gradients (and hence nitrate fluxes) are extremely small. But phosphate and silicate uptake apparently continues, albeit at much lower rates than at the deeper horizons.

\section{Discussion}

[23] We are certain that these fluxes are driven by biological uptake. The close coherence in near-Redfield proportions (Figure 7) between fluxes across the front, despite differing deep water silicate and phosphate concentrations [Hales et al., 2009], suggests that simple mixing between high- and low-nutrient water masses does not drive the fluxes. The strong depletion of the fluxes between the $1 \%$ light level and the pycnocline further suggests biological uptake: in order for this to be the result of physical mixing, complicated interleaving of water masses and current shear would be required. Examination of $T-S$ relationships and ADCP velocity distributions during this study [Houghton et al., 2006, 2009] show nothing of the sort. These flux distributions are largely consistent with the broad patterns of biomass (Figure 8) seen during these surveys. Optical backscatter, beam attenuation, and chlorophyll fluorescence are all bounded primarily by the pycnocline above and the $1 \%$ light level below. One exception is the deep shoreward plume of high backscatter (sensor voltages of $0.3-0.5 \mathrm{~V}$ below the $1 \%$ light level at and shoreward of the front) in the absence of correspondingly elevated chlorophyll fluorescence or beam attenuation that Hales et al. [2009] identified as

@ 1\% light level
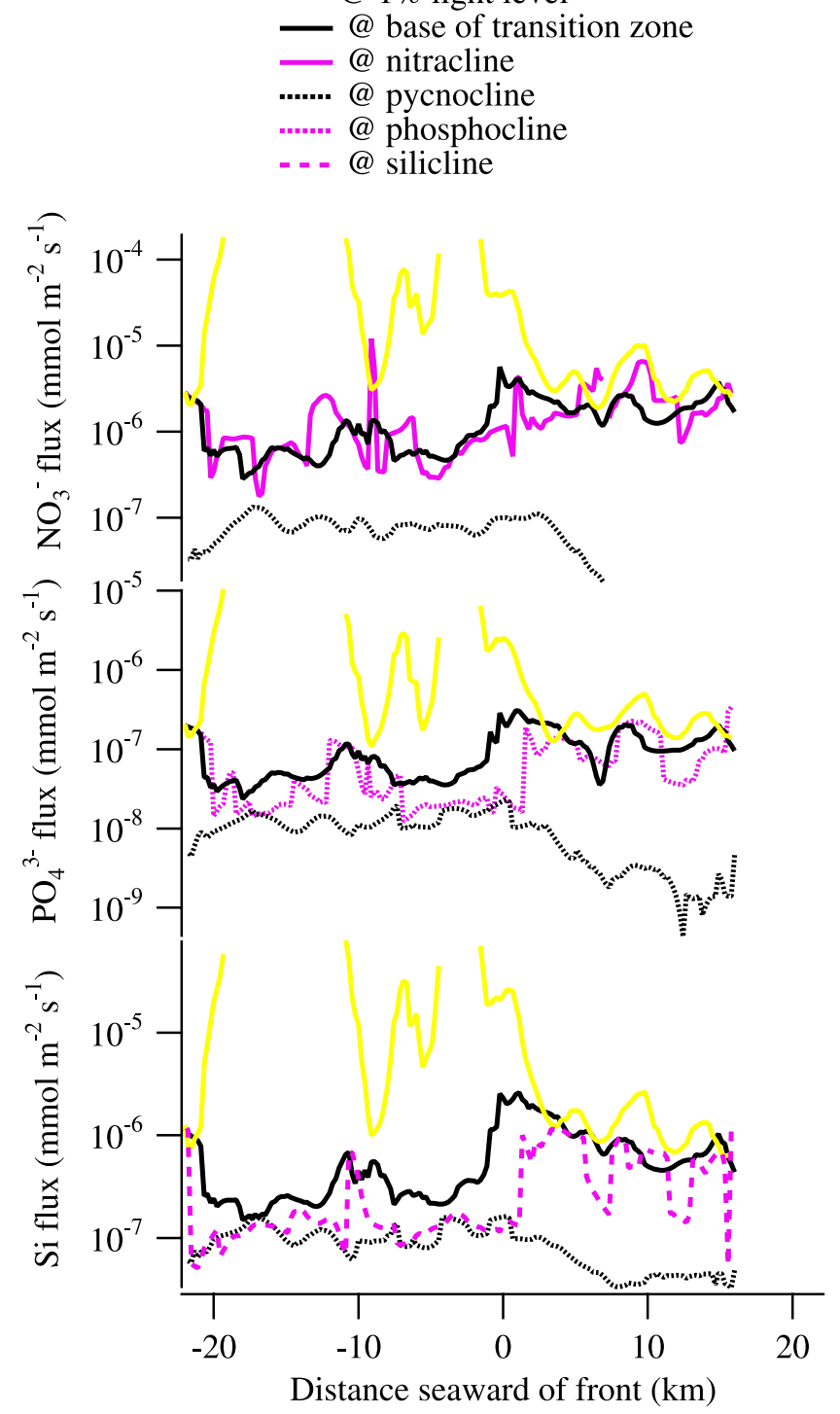

Figure 6. Nutrient fluxes at hydrographic horizons across the front. Fluxes are shown for all three nutrients at the 1\% light level (yellow lines); the base of the density transition zone (solid black line); the pycnocline (dotted black lines); and the three nutriclines (magenta lines). 


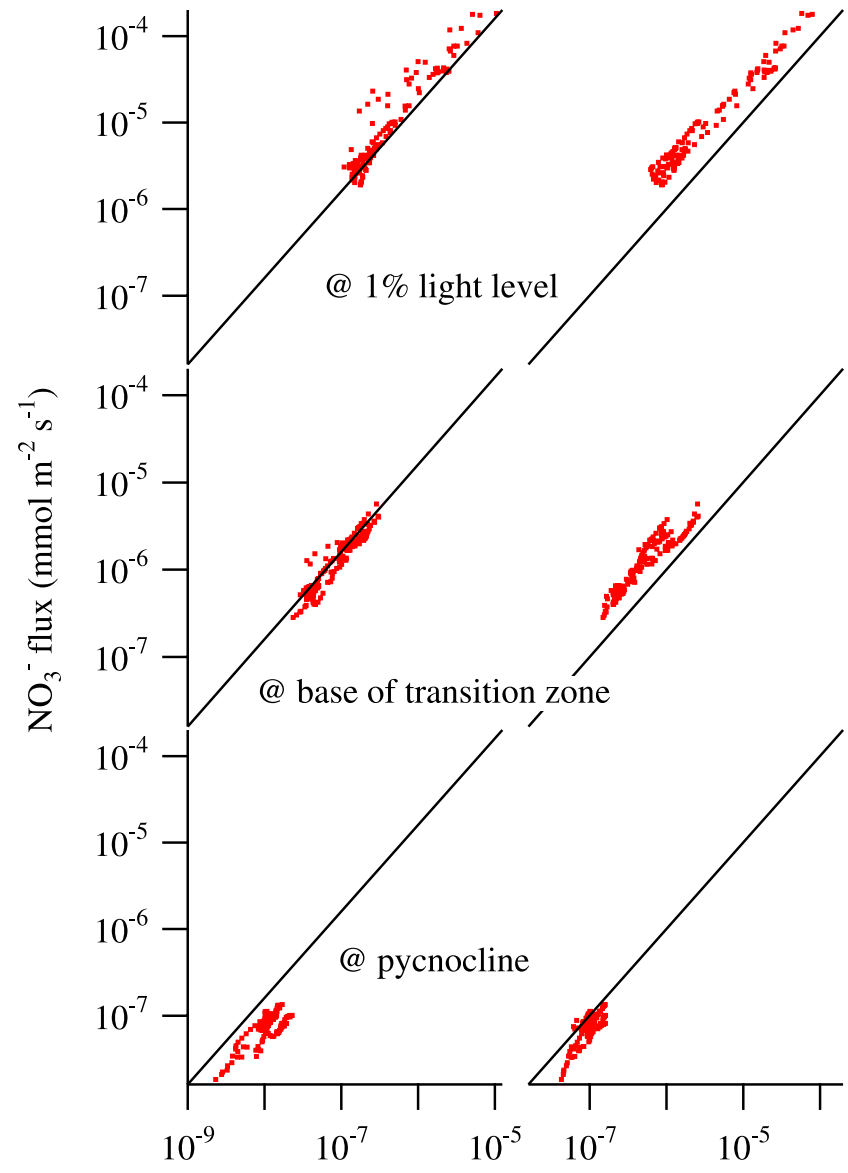

$\mathrm{PO}_{4}{ }^{3-}$ flux $\left(\mathrm{mmol} \mathrm{m}{ }^{-2} \mathrm{~s}^{-1}\right) \quad$ Si flux $\left(\mathrm{mmol} \mathrm{m}^{-2} \mathrm{~s}^{-1}\right)$

Figure 7. Nutrient flux relationships (top) at the $1 \%$ light level, (middle) at the base of the density transition zone, and (bottom) at the pycnocline. Black lines represent Redfield stoichiometry: $16 \mathrm{~N}: 1 \mathrm{P}$ in Figure 7 (left) and $1 \mathrm{~N}: 1 \mathrm{Si}$ in Figure 7 (right).

originating from shelf bottom boundary layer waters, following Barth et al. [1998] and Boss et al. [2001a, 2001b, 2004], which we do not believe is photosynthetically active material. Finally, the coincidence of a nitrite maximum with the $1 \%$ light level as shown by Hales et al. [2009] suggests active, albeit inefficient, photosynthetic nitrate uptake in low-light conditions [Lomas and Lipschulz, 2006].

[24] The most significant finding from the preceding results is that the shoaled density transition zone shoreward of the front provides substantial overlap of significant nutrient gradients with elevated mixing rates within the euphotic zone. This leads to a large shoreward enhancement of vertical nutrient fluxes relative to seaward fluxes at the $1 \%$ light level, which begins immediately at the front. Fluxes through the $1 \%$ light level at and shoreward of the front averaged about $6 \times 10^{-5} \mathrm{mmol} \mathrm{NO}_{3}^{-} \mathrm{m}^{-2} \mathrm{~s}^{-1}$ (Table 1). This is enough to support about $30 \mathrm{mmol} \mathrm{C} \mathrm{m} \mathrm{m}^{-2} \mathrm{~d}^{-1}$ of net productivity if all the upward transported $\mathrm{NO}_{3}^{-}$were consumed by phytoplankton. In contrast, the upward transport through the $1 \%$ light level seaward of the front is over five times less, only about $1 \times 10^{-5} \mathrm{mmol} \mathrm{m}^{-2} \mathrm{~s}^{-1}$, enough to support a net productivity of about $5 \mathrm{mmol} \mathrm{C} \mathrm{m}{ }^{-2} \mathrm{~d}^{-1}$, which approximates the low productivity of the Sargasso Sea inferred from time series of inorganic carbon at the Bermuda Atlantic Time-series Study site [Bates et al., 1996; Michaels et al., 1994].

[25] The elevated nutrient fluxes through the base of the euphotic zone shoreward of the front are the result of the upward displacement of the density transition zone immediately shoreward of the front, while the euphotic depths penetrate below this zone of stratification. This results in increased mixing rates at the $1 \%$ light level shoreward of the front, and persistence of significant nutrient gradients to these depths results in large upward nutrient fluxes.

[26] The physical mechanism that maintains the separation between the base of the density transition zone and 1\% light level shoreward of the front is unclear. Model studies [e.g., Gawarkiewicz and Chapman, 1992; Chapman and Lentz, 1994] and observations [e.g., Houghton, 1997; Houghton and Visbeck, 1998; Barth et al., 1998; Pickart, 2000; Barth et al., 2004] have suggested that the secondary circulation occurring at the shelf break front consists of convergent flow at the foot of the front and upwelling along the sloping isopycnals. The models suggest that secondary flow diverges at the top of the front and results in downwelling flow on either side of the front. This portion of the circulation cells has not been observed. From ADCP data, there is horizontal convergent cross-shelf flow at the depth of the along-slope jet [Pickart, 2000; Frantantoni et al.,

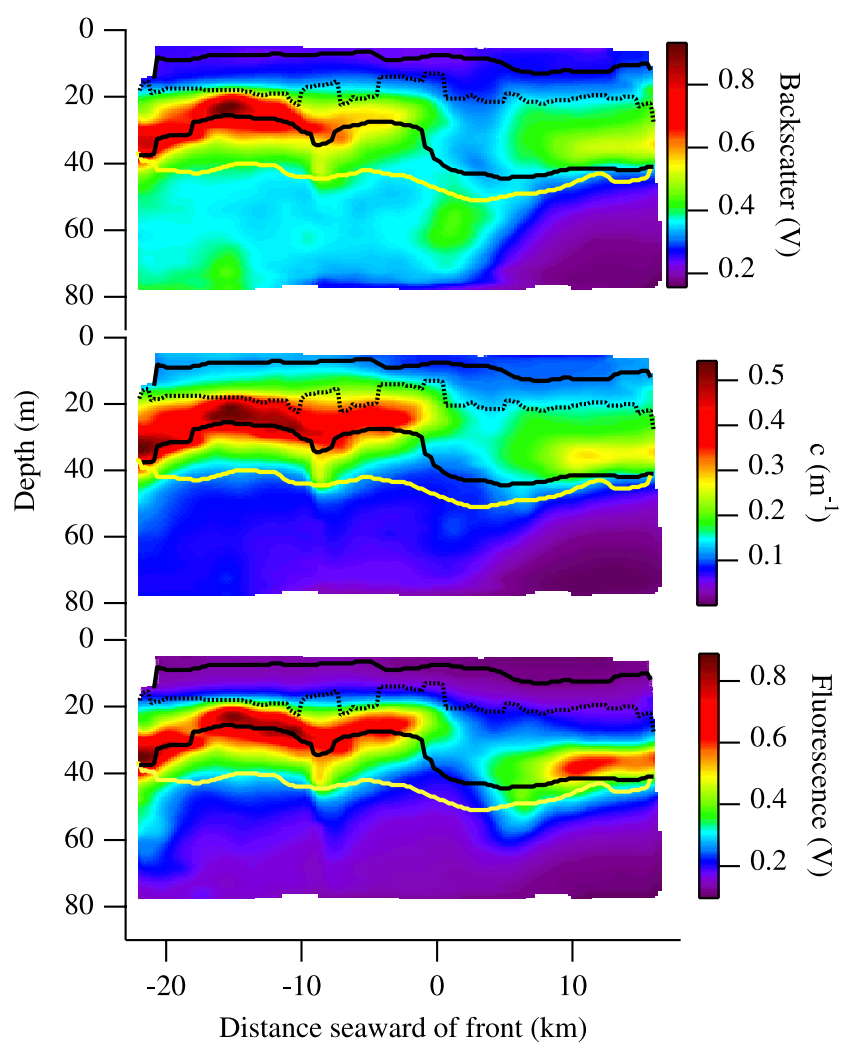

Figure 8. Optical measures of biomass. (top) Optical backscatter (uncalibrated sensor voltage), (middle) relative beam attenuation, and (bottom) chlorophyll fluorescence (uncalibrated sensor voltage). Lines representing the density transition zone and 1\% light level are as in Figure 2. 
Table 1. Nitrate Fluxes at Selected Property Horizons ${ }^{\mathrm{a}}$

\begin{tabular}{lcccc}
\hline & \multicolumn{4}{c}{ Horizon } \\
\cline { 2 - 5 } \multicolumn{1}{c}{ Location } & \multicolumn{1}{c}{ B Light Level } & Nitracline & Base of Density Transition Zone & Pycnocline \\
\hline Shoreward of front & $6 \times 10^{-5} \pm 3 \times 10^{-5}$ & $2 \times 10^{-6} \pm 7 \times 10^{-7}$ & $1 \times 10^{-6} \pm 4 \times 10^{-7}$ & $1 \times 10^{-7} \pm 3 \times 10^{-8}$ \\
Seaward of front & $1 \times 10^{-5} \pm 6 \times 10^{-6}$ & $3 \times 10^{-6} \pm 1 \times 10^{-6}$ & $2 \times 10^{-6} \pm 6 \times 10^{-7}$ & $1 \times 10^{-7} \pm 2 \times 10^{-8}$ \\
\hline${ }^{a}$ Nitrate fluxes are in mmol m${ }^{-2} \mathrm{~s}^{-1}$. & & &
\end{tabular}

2001; Flagg et al., 2006; Houghton et al., 2009]. Whether this convergent flow increases the strength of the jet or results in upwelling is not clear. With the data available, it is not possible to determine whether there is a significant convergence or divergence in the cross-slope flow that would indicate a vertical velocity as predicted in the models. Thus, on the basis of the model studies and field observations, we have no evidence to support vertical motions on the shoreward side of the front that would keep the base of the density transition layer and biomass layer above the $1 \%$ light level.

[27] Such a scenario requires discussion of the possible mechanisms whereby euphotic depths remain slightly shallower shoreward of the front than seaward (by only about $3 \mathrm{~m}$ ), while the biomass maxima shoreward of the front is much shallower (by about $10 \mathrm{~m}$ ). In other words, why does phytoplankton biomass not "grow down" into the favorable light and nutrient conditions at the base of the euphotic zone immediately shoreward of the front? Two possibilities come immediately to mind. The first is that grazers are active in the lower light levels below the biomass maxima, and phytoplankton biomass does not build to the high levels seen farther up in the density transition zone because of this increased loss term. Unfortunately, we had no zooplankton or grazing rate component in this study and cannot definitively comment on this possibility. Our measurements of ammonium (data not shown), however, showed no enrichments that might indicate enhanced grazing activity at these depths. Further, our own measurements of degraded phaeopigments (data not shown) did not imply a grazing source. Thus, we have no information indicating high grazing activity but cannot rule it out.

[28] The second possibility is the vertical variability of the physical mixing. Turbulent mixing rates at the base of the density transition zone are 1-2 orders of magnitude smaller than they are at the $1 \%$ light level. It is easier for biomass to accumulate in the lower turbulence of the more stable density transition zone than at the base of the euphotic zone. Mixing rates at the base of the euphotic zone were in the range of $10^{-4}-10^{-3} \mathrm{~m}^{2} \mathrm{~s}^{-1}$. Very roughly, such mixing rates could move a parcel of water $10 \mathrm{~m}$ vertically in $0.5-$ 5 days. These mixing timescales are similar to specific plankton growth timescales calculated for the irradiance levels and chlorophyll: $\mathrm{C}$ ratios observed in this study at the base of the euphotic zone (approximately $0.3 \mathrm{~d}^{-1}$, following Behrenfeld et al. [2005], Geider et al. [1997, 1998], or Cullen et al. [1992]). The similarity of the growth and transport times suggests that the high mixing rates at these depths may prevent biomass accumulation. In comparison, the specific growth rates are severalfold higher and the mixing rates are $1-2$ orders of magnitude lower in the range between the base of the density transition zone and the pycnocline, leading to conditions much more favorable for biomass accumulation.
[29] The majority of the nutrient uptake appears to be by nonsilicifying organisms. At the base of the euphotic zone, the average ratio of nitrate flux to silicate flux is about $3: 1$ (Figure 7). Healthy, iron-replete diatoms take up about one nitrate for every silicate [Dugdale and Wilkerson, 1998], so this ratio suggests that diatoms are consuming at most only about a quarter of the nitrate flux. There appears to be no difference in this ratio across the front at this depth horizon.

[30] Nutrient fluxes fall off dramatically on shallower horizons. By the depth of the pycnocline, fluxes of all nutrients are a hundredfold lower than those seen at the $1 \%$ light level, regardless of position relative to the front. Seaward of the front, the flux decrease occurs mostly between the base of the density transition zone and the pycnocline, while shoreward of the front, the decrease comes mostly between the $1 \%$ light level and the base of the density transition zone.

[31] The small net fluxes at the pycnocline suggest that whatever biological uptake is occurring there is negligible in comparison to the net community productivity over the euphotic zone. Nonetheless, the distinct flux ratios at the pycnocline, the persistence of weak phosphate and silicate gradients above this depth, and the existence of low but detectable bio-optical signatures of backscatter and beam attenuation are suggestive of biological activity that is distinct from that driving the majority of the nutrient uptake. Bandstra et al. [2006] suggested that calcareous phytoplankton might be occupying these shallow depths on the basis of cross-frontal variations in carbonate chemistry and optical backscatter signals. Hales et al. [2009] suggested that nitrogen fixation might be occurring. The flux ratios shown in Figure 7 offer another possibility. The nitrate to silicate flux ratio at the pycnocline is about 0.8 , suggesting a dominant role for silicifying organisms at this depth horizon. This is coincident with a distinctly non-Redfield nitrate to phosphate flux ratio of about 8 at this depth. Others have observed non-Redfield N:P uptake ratios by silicifying plankton, albeit at high latitudes [Arrigo et al., 1999; Hales and Takahashi, 2004]. Possibly, a small size fraction silicifying plankton assemblage is occupying this niche and disproportionately consuming phosphate relative to nitrate.

\section{Conclusions}

[32] Coincident high-resolution measurements were made of nutrient concentrations using the Lamont Pumping SeaSoar, and measurements were made of turbulent mixing using a high-frequency microstructure instrument (TOMASI). We were able to examine vertical fluxes through several hydrographic surfaces spanning the New England shelf break front. Large biological nutrient uptake occurred shoreward of the front, supported by vertical fluxes through the $1 \%$ light level that resulted from the juxtaposition of high mixing rates with 
elevated vertical nutrient gradients below the base of the density transition zone. The mechanism maintaining the separation between the $1 \%$ light level and the base of the density transition zone on the shoreward side of the front is not clear from the results of this study. Vertical nutrient fluxes through the $1 \%$ light level were low seaward of the front, where the $1 \%$ light level did not extend into waters with elevated mixing rates. Upward nutrient fluxes were almost entirely consumed by the time they reached the depth of the pycnocline, suggesting that most of the primary productivity available for export occurred in this depth range. Differences in flux ratios on these surfaces suggest the presence of a shallow community of silicifying phytoplankton that consumes phosphate in excess of Redfield proportion to nitrate, although their activity makes up only a tiny fraction of the net community productivity that could be supported by the upward nutrient fluxes at the base of the euphotic zone.

[33] Acknowledgments. We thank the captain and crew of the R/V Endeavor for their support of the science operations and provision of their knowledge of local waters and fishing activities in the study area. We also thank Bob Houghton for his leadership of this project. Paul Covert and Dale Hubbard were instrumental in the successful deployment and operation of the LPS system and the collection of high-quality nutrient data. Mark Prater provided valuable assistance with the shipboard troubleshooting and operation of the TOMASI. This work was supported by NSF grants OCE-002754 (Hebert), OCE-002755 (Hales), and OCE-002390 (Marra).

\section{References}

Arrigo, K. R., D. H. Robinson, D. L. Worthen, R. B. Dunbar, G. R. DiTullio, M. Van Woert, and M. P. Lizotte (1999), Phytoplankton community structure and the drawdown of nutrients and $\mathrm{CO}_{2}$ in the Southern Ocean, Science, 283, 365-367, doi:10.1126/science.283.5400.365.

Bandstra, L., B. Hales, and T. Takahashi (2006), High-frequency measurements of total $\mathrm{CO}_{2}$ : Method development and first oceanographic observations, Mar. Chem., 100, 24-38, doi:10.1016/j.marchem.2005.10.009.

Barth, J. A., D. Bogucki, S. D. Pierce, and P. M. Kosro (1998), Secondary circulation near a shelfbreak front, Geophys. Res. Lett., 25, 2761-2764, doi:10.1029/98GL02104.

Barth, J. A., D. Hebert, A. C. Dale, and D. S. Ullman (2004), Direct observations of along-isopycnal upwelling and diapycnal velocity at a shelfbreak front, J. Phys. Oceanogr., 34, 543-565, doi:10.1175/2514.1.

Batchelor, G. (1959), Small-scale variation of convected quantities like temperature in turbulent fluid, J. Fluid Mech., 5, 113-133, doi:10.1017/S002211205900009X.

Bates, N. R., A. F. Michaels, and A. H. Knapp (1996), Seasonal and interannual variability of oceanic carbon dioxide species at the U. S. JGOFS Bermuda Atlantic Time-series Study (BATS) site, Deep Sea Res., Part II, 43, 347-383, doi:10.1016/0967-0645(95)00093-3.

Behrenfeld, M. J., E. Boss, D. A. Siegel, and D. M. Shea (2005), Carbonbased ocean productivity and phytoplankton physiology from space, Global Biogeochem. Cycles, 19, GB1006, doi:10.1029/2004GB002299.

Boss, E., W. S. Pegau, W. D. Gardner, J. R. V. Zaneveld, A. H. Barnard, M. S. Twardowski, G. C. Chang, and T. D. Dickey (2001a), Spectral particulate attenuation and particle size distribution in the bottom boundary layer of a continental shelf, J. Geophys. Res., 106, 9509-9516, doi:10.1029/2000JC900077.

Boss, E., W. S. Pegau, J. R. V. Zaneveld, and A. H. Barnard (2001b), Spatial and temporal variability of absorption by dissolved material at a continental shelf, J. Geophys. Res., 106, 9499-9507, doi:10.1029/ 2000JC900008.

Boss, E., W. S. Pegau, M. Lee, M. Twardowski, E. Shybanov, G. Korotaev, and F. Baratange (2004), Particulate backscattering ratio at LEO 15 and its use to study particle composition and distribution, J. Geophys. Res., 109, C01014, doi:10.1029/2002JC001514.

Chapman, D. C., and S. J. Lentz (1994), Trapping of a coastal density front by the bottom boundary layer, J. Phys. Oceanogr., 24, 1464-1479, doi:10.1175/1520-0485(1994)024<1464:TOACDF>2.0.CO;2.

Cullen, J. J., M. R. Lewis, C. O. Davis, and R. T. Barber (1992), Photosynthetic characteristics and estimated growth rates indicate grazing is the proximate control of primary production in the equatorial Pacific, J. Geophys. Res., 97, 639-654, doi:10.1029/91JC01320.
Dillon, T. M. (1982), Vertical overturns: A comparison of Thorpe and Ozmidov length scales, J. Geophys. Res., 87, 9601-9613, doi:10.1029/ JC087iC12p09601.

Dillon, T. M., J. A. Barth, A. Y. Erofeev, G. H. May, and H. W. Wijesekera (2003), MicroSoar: A new instrument for measuring microscale turbulence from rapidly moving submerged platforms, J. Atmos. Oceanic Technol., 20, 1671-1684, doi:10.1175/1520-0426(2003)020<1671:MANIFM> 2.0.CO;2.

Dugdale, R. C., and F. P. Wilkerson (1998), Silicate regulation of new production in the equatorial Pacific upwelling, Nature, 391, 270-273, doi: $10.1038 / 34630$.

Flagg, C. N., M. Dunn, D.-P. Wang, H. T. Rossby, and R. L. Benway (2006), A study of the currents of the outer shelf and upper slope from a decade of shipboard ADCP observations in the Middle Atlantic Bight, J. Geophys. Res., 111, C06003, doi:10.1029/2005JC003116.

Frantantoni, P. S., R. S. Pickart, D. J. Torres, and A. Scotti (2001), Mean structure and dynamics of the shelfbreak jet in the Middle Atlantic Bight during fall and winter, J. Phys. Oceanogr., 31, 471-488.

Gawarkiewicz, G., and D. C. Chapman (1992), The role of stratification in the formation and maintenance of shelf break fronts, J. Phys. Oceanogr., 22, 753-772, doi:10.1175/1520-0485(1992)022<0753:TROSIT >2.0.CO;2.

Geider, R. J., H. L. Macintyre, and T. M. Kana (1997), Dynamic model of phytoplankton growth and acclimation: Responses of the balanced growth rate and the chlorophyll a:carbon ratio to light, nutrient-limitation and temperature, Mar. Ecol. Prog. Ser., 148, 187-200, doi:10.3354/meps148187.

Geider, R. J., H. L. Macintyre, and T. M. Kana (1998), A dynamic regulatory model of phytoplankton acclimation to light, nutrients, and temperature, Limnol. Oceanogr., 4, 679-694.

Gregg, M. C. (1999), Uncertainties and limitations in measuring $\varepsilon$ and $\chi_{T}$, J. Atmos. Oceanic Technol., 16, 1483-1490, doi:10.1175/15200426(1999)016<1483:UALIMA > 2.0.CO;2.

Hales, B., and T. Takahashi (2002), The Pumping SeaSoar: A high resolution seawater sampling platform, J. Atmos. Oceanic Technol., 19, 10961104.

Hales, B., and T. Takahashi (2004), High-resolution biogeochemical investigation of the Ross Sea, Antarctica, during the AESOPS (U. S. JGOFS) program, Global Biogeochem. Cycles, 18, GB3006, doi:10.1029/ 2003 GB002165.

Hales, B., A. van Geen, and T. Takahashi (2004), High-frequency measurement of seawater chemistry: Flow-injection analysis of macronutrients, Limnol. Oceanogr. Methods, 2, 91-101.

Hales, B., J. N. Moum, P. Covert, and A. Perlin (2005), Irreversible nitrate fluxes due to turbulent mixing in a coastal upwelling system, J. Geophys. Res., 110, C10S11, doi:10.1029/2004JC002685.

Hales, B., L. Karp-Boss, A. Perlin, and P. Wheeler (2006), Oxygen production and carbon sequestration in an upwelling coastal margin, Global Biogeochem. Cycles, 20, GB3001, doi:10.1029/2005GB002517.

Hales, B., R. Vaillancourt, L. Prieto, J. Marra, R. Houghton, and D. Hebert (2009), High-resolution surveys of the biogeochemistry of the New England shelfbreak front during summer, 2002, J. Mar. Syst., doi:10.1016/ j.jmarsys.2008.11.024, in press.

Houghton, R. W. (1997), Lagrangian flow at the foot of a shelfbreak front using a dye tracer injected into the bottom boundary layer, Geophys. Res. Lett., 24, 2035-2038, doi:10.1029/97GL02000.

Houghton, R. W., and J. Marra (1983), Physical/biological structure and exchange across the thermohaline shelf/slope front in the New York Bight, J. Geophys. Res., 88, 4467-4481, doi:10.1029/JC088iC07p04467.

Houghton, R. W., and M. Visbeck (1998), Upwelling and convergence in the Middle Atlantic Bight, Geophys. Res. Lett., 25, 2765-2768, doi:10.1029/98GL02105.

Houghton, R. W., D. Hebert, and M. Prater (2006), Circulation and mixing at the New England shelfbreak front: Results of purposeful tracer experiments, Prog. Oceanogr., 70, 289-312, doi:10.1016/j.pocean.2006.05.001.

Houghton, R. W., R. D. Vaillancourt, J. Marra, D. Hebert, and B. Hales (2009), Cross-shelf circulation and phytoplankton distribution at the summertime New England shelfbreak front, J. Mar. Syst., doi:10.1016/ j.jmarsys.2008.11.023, in press.

Itsweire, E. C. (1984), Measurements of vertical overturns in a stably stratified turbulent flow, Phys. Fluids, 27, 764-766, doi:10.1063/ 1.864704 .

Johnston, T. M. S., and D. L. Rudnick (2009), Observations of the transition layer, J. Phys. Oceanogr., doi:10.1175/2008JPO3824.1 in press.

Klymak, J. M., R. Pinkel, and L. Rainville (2008), Direct breaking of the internal tide near topography: Kaena Ridge, Hawaii, J. Phys. Oceanogr., 38, 380-399, doi:10.1175/2007JPO3728.1.

Ledwell, R., D. J. McGillicuddy Jr., and L. A. Anderson (2008), Nutrient flux into an intense deep chlorophyll layer in a mode-water eddy, Deep Sea Res., Part II, 55, 1139-1160, doi:10.1016/j.dsr2.2008.02.005.

Letelier, R. M., D. M. Karl, M. R. Abbott, and R. R. Bidigare (2004), Light driven seasonal patterns of chlorophyll and nitrate in the lower euphotic 
zone of the North Pacific Subtropical Gyre, Limnol. Oceanogr., 49, $508-$ 519.

Lewis, M. R., W. G. Harrison, N. S. Oakley, D. Hebert, and T. Platt (1986), Vertical nitrate fluxes in the oligotrophic ocean, Science, 234, 870-873, doi:10.1126/science.234.4778.870.

Lomas, M. W., and F. Lipschulz (2006), Forming the primary nitrite maximum: Nitrifiers or phytoplankton?, Limnol. Oceanogr., 51, 2453-2467.

Malone, T. C., T. S. Hopkins, P. G. Falkowski, and T. E. Whitledge (1983), Production and transport of phytoplankton biomass over the continental shelf of the New York Bight, Cont. Shelf Res., 1, 305-337, doi:10.1016/ 0278-4343(83)90001-8.

Marra, J. (2004), The compensation irradiance for phytoplankton in nature, Geophys. Res. Lett., 31, L06305, doi:10.1029/2003GL018881.

Marra, J., R. W. Houghton, and C. Garside (1990), Phytoplankton growth at the shelf-break front in the Middle Atlantic Bight, J. Mar. Res., 48, 851868.

Michaels, A. F., et al. (1994), Seasonal patterns of ocean biogeochemistry at the U. S. JGOFS Bermuda Atlantic Time-series Study site, Deep Sea Res., Part I, 41, 1013-1038, doi:10.1016/0967-0637(94)90016-7.

Morel, A., and S. Maritorena (2001), Bio-optical properties of oceanic waters: A reappraisal, J. Geophys. Res., 106, 7163-7180, doi:10.1029/ 2000JC000319

Moum, J. N. (1996), Energy-containing scales of turbulence in the ocean thermocline, J. Geophys. Res., 101, 14,095-14,100, doi:10.1029/ 96JC00507.

Mudge, T. D., and R. G. Lueck (1994), Digital signal processing to enhance oceanographic observations, J. Atmos. Oceanic Technol., 11, 825-836, doi:10.1175/1520-0426(1994)011<0825:DSPTEO>2.0.CO;2.

Osborn, T. R. (1980), Estimates of the local rate of vertical diffusion from dissipation measurements, J. Phys. Oceanogr., 10, 83-89, doi:10.1175/ 1520-0485(1980)010<0083:EOTLRO >2.0.CO;2.

Osborn, T. R., and C. C. Cox (1972), Oceanic fine structure, Geophys. Astrophys. Fluid Dyn., 3, 321-345, doi:10.1080/03091927208236085.

Pacanowski, R. C., and G. Philander (1981), Parameterization of vertical mixing in numerical models of the tropical ocean, J. Phys. Oceanogr., 11, $1443-$ 1451, doi:10.1175/1520-0485(1981)011<1443:POVMIN>2.0.CO;2.

Pickart, R. T. (2000), Bottom boundary layer structure and detachment in the shelfbreak jet of the Middle Atlantic Bight, J. Phys. Oceanogr., 30, 26682686, doi:10.1175/1520-0485(2001)031<2668:BBLSAD>2.0.CO;2.
Rainville, L., and P. Winsor (2008), Mixing across the Arctic Ocean: Microstructure observations during the Beringia 2005 Expediation, Geophys. Res. Lett., 35, L08606, doi:10.1029/2008GL033532.

Robertson, R. (2006), Modeling internal tides over Fieberling Guyot: Resolution, parameterization, performance, Ocean Dyn., 56, 430-444, doi:10.1007/s10236-006-0062-5.

Ryan, J. P., J. A. Yoder, and P. C. Cornillon (1999a), Enhanced chlorophyll at the shelfbreak of the Mid-Atlantic Bight and Georges Bank during the spring transition, Limnol. Oceanogr., 44, 1-11.

Ryan, J. P., J. A. Yoder, J. A. Barth, and P. C. Cornillon (1999b), Chlorophyll enhancement and mixing associated with meanders of the shelf break front in the Mid-Atlantic Bight, J. Geophys. Res., 104, 23,479-23,493, doi:10.1029/1999JC900174.

Strutton, P., and F. Chavez (2004), Biological heating in the equatorial Pacific: Observed variability and potential for real-time calculation, J. Clim., 17, 1097-1109, doi:10.1175/1520-0442(2004)017<1097:BHITEP>2.0.CO;2.

Thorpe, S. A. (1977), Turbulence and mixing in a Scottish loch, Philos. Trans. R. Soc. London, Ser. A, 286, 125-181, doi:10.1098/rsta.1977.0112.

Vaillancourt, R., J. Marra, R. Houghton, L. Prieto, B. Hales, and D. Hebert (2005), Light absorption and scattering by particles and CDOM at the New England shelfbreak front, Geochem. Geophys. Geosyst., 6, Q11003, doi:10.1029/2005GC000999.

Washburn, L., T. F. Duda, and D. C. Jacobs (1996), Interpreting conductivity microstructure: Estimating the temperature variance dissipation rate, J. Atmos. Oceanic Technol., 13, 1166-1188, doi:10.1175/15200426(1996)013<1166:ICMETT>2.0.CO;2.

B. Hales, College of Oceanic and Atmospheric Sciences, Oregon State University, 104 COAS Administration Building, Corvallis, OR 97331, USA. (bhales@coas.oregonstate.edu)

D. Hebert, Graduate School of Oceanography, University of Rhode Island, 215 South Ferry Road, Narragansett, RI 02882-1197, USA. (hebert@gso.uri.edu)

J. Marra, Aquatic Research and Environmental Assessment Center, Brooklyn College, 123 Ingersoll Hall Extension, Brooklyn, NY 11210, USA. (jfm7780@brooklyn.cuny.edu) 